\title{
PEMAKAIAN BAHASA INDONESIA KARYA TULIS ILMIAH OLEH MAHASISWA UNIVERSITAS PEMBANGUNAN NASIONAL "VETERAN" JAKARTA
}

\author{
Kasno Atmo Sukarto \\ Universitas Nasional, Jakarta \\ 0817767736 \\ pos el: kasnoas@yahoo.com
}

Received April 6, 2020, Revised June 11, 2020, Approved June 16, 2019

\begin{abstract}
ABSTRAK
Dalam tulisan tugas karya ilmiah mahasiswa Jurusan Manajemen Akuntansi, Fakultas Ekonomi dan Bisnis, UPN "Veteran" Jakarta, masih dijumpai adanya kesalahan penerapaan ejaan, diksi, dan pengalimatan yang kurang efektif. Tujuan penelitian ini adalah untuk mendeskripsikan kesalahan penerapan ejaan, diksi, dan kalimat efektif. Metode yang digunakan dalam penelitian adalah metode desktiptif kualitatif, yaitu mendeskripsikan data yang terpilih yang terkait dengan kesalahan ejaan, diski, dan kalimat efektif. Adapun acuan untuk menganalisis data penulis menggunakan Pedoman Umum Ejaan Bahasa Indonesia, edisi tahun 2016. Untuk menganalisis pengalimatan, penulis mengacu pada Bahasa Indonesia: Dasar-Dasar Pengembangan Kepribadian, edisi tahun 2018. Hasil penelitian ini dapat disimpulkan bahwa dalam tugas karya ilmiah mahsiswa, terdapat kesalahan seperti berikut. 1) Penerapan ejaan khusunya penulisan singkatan nama sifat Tuhan, singkatan gelar, penulisan nama dalam sebuah kutipan, dan Penulisan unsur-unsur bahasa asing. 2) pilihan kata yang kurang tepat yang belum sesuai dengan konteksnya. 3) Terdapat kekeliruan dalam membuat kalimat, seperti kurang cermat dalam menyikapi ekonomi bahasa, konjungsi, dan ketikdakjelasan subjek.
\end{abstract}

Kata Kunci: ejaan, diksi, pengalimatan

\begin{abstract}
In writing of scientific assignments of the Accounting Management Department's students, Faculty of Economics and Business, UPN "Veterans" Jakarta, there are still spelling errors, diction, and ineffective wording. This study aims at describing the errors in the application of spelling, diction and effective sentences. The method used in this research is a qualitative descriptive method, which describes the selected data related to spelling errors, discourse, and effective sentences. The writer used Pedoman Umum Ejaan Bahasa Indonesia, 2016 edition, as reference. To analyze the wording, the writer refers to Bahasa Indonesia: Dasar-Dasar Pengembangan Kepribadian, 2018 edition. The findings are; 1) Application of the spelling especially writing the abbreviation for the name of the attribute of God, abbreviation for the title, writing the name in a quote, and writing the elements of a foreign language. 2) improper choice of words that do not fit the context. 3) There are mistakes in making sentences, such as inaccuracy in dealing with the economics of language, conjunctions, and typing obscurity of the subject.
\end{abstract}

Keywords: spelling, diction, wording

\section{PENDAHULUAN}

\section{Latar Belakang}

Bahasa Indonesia sebagai alat komunikasi antaranggota masyarakat baik secara perorangan maupun kelompok mempunyai dua fungsi, yaitu sebagai bahasa lisan dan sebagai Bahasa tulis. Sebagai bahasa lisan bahasa Indonesia, misalnya dipakai sebagai alat komunikasi 
Jurnal Pujangga Volume 6, Nomor 1, Juni 2020

ISSN P 2443-1478

ISSN E 2443-148

antarsesama teman sejawat. Dalam Bahasa lisan ini atau lebih tepat kita sebut ragam bahasa lisan, misalnya yang ditekankan adalah masalah lafal. Hal itu sejalan dengan pandangan Sugono (1997: 14) yang menyatakan bahwa ragam bahasa lisan adalah yang dihasilkan dengan menggunakan alat ucap (organ of speech) dengan fonem sebagai unsur dasar - dinamakan ragam bahasa lisan. Dengan kata lain, Bahasa lisan berarti penekanan pada lafat atau alat ucap. misalnya ucapan huruf $/ p /$, dan $/ v /$ pada kata pitamin atau vitamin, atau $/ j /$, dan $/ z /$ pada kata jakat atau zakat. Pada tararan lisan memang tidak terlalu kentara perbedaan bunyi $/ p / \mathrm{dan} / \mathrm{v} / \mathrm{atau}$ bunyi /j/ dan / $/$ /. Akan tetapi, pada tataran bahasa lisan yang dituliskan harus jelas penulisannya seperti berikut bukan pitamin dan jakat melainkan vitamin, dan zakat.

Kasus tersebut di atas terjadi pada mahasiswa ketika menulis tugas karya ilmiah, kata yang diungkapkan cenderung terbawa ketika menulis bukan pada sistem penulisan huruf yang tepat sesuai dengan kaidah penulisan huruf, melainkan dalam menulis cenderung mengikuti bunyi huruf yang biasa diucapkan. Hal semacam itu sering dilakukan oleh mahasiswa ketika menulis tugas-tugas harian atau tugas menulis karya tulis ilmiah.

Sebagai bahasa tulis bahasa Indonesia dalam laporan tugas karya ilmiah hendaknya menyikapi kaidah bahasa Indonesia yang berlaku. Sukarto (2018; 2) memberikan pandangan bahwa pemakai bahasa Indonesia dalam konteks pemakaian bahasa Indonesia yang baik dan benar dalam tulisan karya ilmiahnya, penulis cenderung banyak yang tidak sadar bahwa yang telah dipaparkan itu pilihan kata yang tidak tepat atau tidak sesuai dengan topik yang dibicarakan. Kasus lain yang timbul adalah penerapan ejaan dan pengalimatan. Penerapan ejaan dalam pengalimatan misalnya seperti berikut.

(1) Puji Syukur kami ucapkan ke hadirat Allah swt., yang masih memberikan kesempatan dan kesehatan sehingga Karya Tulis Ilmiah ini dapat diselesaikan dalam waktu yang telah ditetapkan.

Pada ucapan terima kasih atau kata pengantar terlihat bahwa masih terlihat adanya kurang kecermatan mahasiswa dalam menulis kata Syukur, swt., kami. Padahal, dalam kuliah tatap muka dan e-leaning sudah diberi sajian ejaan atau acuan wajib yaitu Pedoman Ejaan Bahgasa Indonesia edisi 2016. Dengan cara membaca berulang-ulang, sekurang-kurangnya mahasiswa akan dapat mengerti dan memahami.

Seharusnya kalimat (1) seperi berikut.

(1a) Puji syukur penulis ucapkan ke hadirat Allah Swt. yang masih memberikan kesempatan dan kesehatan, sehingga karya tulis ilmiah ini dapat diselesaikan dalam waktu yang telah ditetapkan.

(1b) Puji syukur saya ucapkan ke hadirat Allah Swt. yang masih memberikan kesempatan dan kesehatan, sehingga karya tulis ilmiah ini dapat diselesaikan dalam waktu yang telah ditetapkan.

Kasus pilihan kata, penerapan kaidah ejaan, termasuk pengalimatan yang lebih lazim disebut kalimat efektif seperti contoh (1) dan (2) masih banyak dilakukan oleh mahasiswa ketika menulis tugas karya ilmiah. Oleh karena itu, terkait dengan tugas karya ilmiah mahasiswa ini, penulis akan mendeskripsikan dan menganalisis kasus kesalahan penerapan ejaan, pilihan kata, 
dan pengalimatan. Dengan cara seperti mendeskripsikan dan menganalisis kesalahan pemakaian bahasa Indonesia, setidaknya akan memberikan gambaran dan pemahaman bagi mahasiswa untuk menyikapi secara positif terhadap bahasa Indonesia. Dengan demikian, dengan cara menggunakan bahasa Indonesia yang baik dan benar, sikap positif mahasiswa terhadap bahasa Indonesia akan terwujud.

\section{Rumusan Masalah}

Berdasarkan latar belakang dan masalah, penelitian difokuskan pada masalah berikut.

1) Kesalahan penerapan ejaan seperti apakah yang muncul dalam tugas karya ilmiah mahasiswa Universitas Pembangunan Nasioanl "Veteran" Jakarta.

2) Kesalahan penerapan diksi seperti apakah yang muncul dalam tugas karya ilmiah mahasiswa Universitas Pembangunan Nasioanl "Veteran" Jakarta.

3) Kesalahan pengalimatan seperti apakah yang muncul dalam tugas karya ilmiah mahasiswa Universitas Pembangunan Nasioanl "Veteran" Jakarta.

\section{Tujuan Penelitian}

Penelitian ini bertujuan untuk

1) mendeskripsikan dan menganalisis kesalahan penerapan ejaan bahasa Indonesia dalam karya tulis ilmiah mahasiswa Universias Pembangunan Nasioanl "Veteran” Jakarta.

2) mendeskripsikan dan menganalisis kesalahan diksi dalam karya tulis ilmiah mahasiswa Universitas Pembangunan Nasioanl "Veteran" Jakarta.

3) mendeskripsikan dan menganalisis pengalimatan dalam karya tulis ilmiah mahasiswa Universitas Pembangunan Nasioanl "Veteran" Jakarta.

\section{Tinjauan Pustaka}

\section{Ikhwal Pemakaian Bahasa}

Mengacu pada penelitian Martin, Mustakim, dan Martha Lena Adriana. yang berjudul Pemakaian Bahasa Indonesia Ragam Tulis di Lingkungan Perguruan Tinggi. (1995: 1) Secara umum dikatakan bahwa amatan sementara-pemakaian bahasa Indonesia-mahasiswa khususnya belum baik dan benar. Selain itu, dalam penelitannya telah dipaparkan analisis kuantitatif mencakup persentase, penyimpangan kaidah bahasa menurut perguruan tinggi, responden, jenis kelamin responden, dan latar belakang bahasa ibu. Analiss kualitatif mencakup ejaan, bentuk kata, pilihan kata, struktur kalimat dan struktur paragraf.

Sementara itu, Gunarwan (1983, dalam Sugiyono dan Sasongko 2014: 101) membuktikan adanya sikap positif dari kalangan mahasiswa terhadap bahasa Indonesia baku. Lebih lanjut dikatakan bahwa hal itu merupakan sikap yang menggembirakan karena sikap tersebut akan berpegaruh terhadap masyarakat yang lain terhadap penggunaan bahasa Indonesia baku. Dengan 
Jurnal Pujangga Volume 6, Nomor 1, Juni 2020

ISSN P 2443-1478

ISSN E 2443-148

kata lain, bahwa bahasa Indonesia masih mendapat tanggapan dan perhatian yang positif oleh mahasiswa. Sikap positif mahasiswa itu perlu adanya penanganan yang khusus, misalnya dengan cara mengevaluasi rencana pembelajaran yang memadai sesuai dengan era millennium. Penyelarasan Satuan Rencana Pembelajaran yang memadai akan dapat meningkatkan kemampuan dan keterampialan mahasiswa dalam menggunakan bahasa Indonesia yang baik dan benar baik secara lisan maupun tulis.

Atas dasar hasil penelitian kedua penulis tersebut di atas, bahwa penelitian tentang pemakaian bahasa Indonesia perlu dilakukan untuk mengetahui seberapa jauh tingkat kemampuan mahasiswa dalam menggunakan bahasa Indonesia baik secara lisan maupun tulis. Penggunaan secara lisan, mahasiswa mampu berkomunikasi dengan teman tutur secara baik berdasarkan konteks, tujuan, dan selaras dengan tempat dan situasi. Secara tulis, mahasiswa mampu menerapkan kaidah bahasa Indonesia dalam menulis karya ilmiah baik karya ilmiah sederhana maupun skripsi. Hal itu sesuai dengan pandangan Kasno (2012: 24) yang menyatakan bahwa pemakaian bahasa Indonesia yang dimaksud adalah bagaimana menerapkan dan memilih kosakata (kata), frasa, klausa, dan kalimat dalam sebuah tulisan. Pemakaian dan penerapan kaidah bahasa Indonesia dalam karya tulis ilmiah adalah tidak bisa dihindari. Untuk itu, sikap positif mahasiswa dalam penerapan kaidah bahasa Indonesia dalam karya tulis ilmiah perlu dilakukan. Dengan demikian, hasil tulisan karya ilmiah mahasiswa akan semakin berkualitas.

\section{Ihwal Bahasa Indonesia}

Sutan Takdir Alisjahbana (STA, 1988, dalam Sukarto, 2016: 64) mengancangkan adanya pembelajaran Bahasa Indonesia di Perguruan Tinggi - karena bahasa Indonesia tidak akan bisa berkembang secara dinamis tanpa adanya penanganan yang khusus oleh para pempinan lembaga terkait dan pakar-pakar bahasa di perguruan tinggi. Oleh karena itu, atas dasar pandangan STA itu, mata kuliah Bahasa Indonesia di perguruan tinggi perlu dikaji ulang, mengingat betapa pentingnya bahasa Indonesia sebagai sarana untuk menginformasikan ilmu pengetahuan dan teknologi agar hasil karya ilmiah mahasiswa khusunya dapat diakses oleh khalayak yang memerlukannya. Hal itu mengacu pada fungsi bahasa Indonesia sebagai bahasa negara, Halim (1980 dalam Sukarto, 2018: 13-16) bahwa Bahasa Indonesia sebagai bahasa pengantar dalam dunia pendidikan, dan sbagai alat tlat pengembangan ilmu pegetahuann dan teknologi. Atas dasar butir fungsi bahasa Indonesia sebagai bahasa negara itu, tidak keliru jika mahasiswa mau menyikapi secara positif terhadap Bahasa Indonesia sebagai Bahasa negara.

Berdasarkan paparan di atas, bahwa bahasa Indonesia di perguruan tinggi perlu ditingkatkan kualitas belajar-mengajarnya. Hal itu mengingat bahwa mahasiswa peserta mata kuliah Bahasa Indonesia bukan sekedar diberi teori atau dapat menguasai teori, melainkan perlu penekanan pada praktik baik secara lisan maupun tertulis. Secara lisan mahasiswa diharapkan dapat berkomunikasi secara lisan dengan menempatkan situasi, tujuan pembicaraan, dan tempat di mana pembicaraan berlangsung. Secara tertulis, mahasiswa diharapkan sekurang-kurangnya mampu menulis karya ilmiah sederhana pada akhir perkuliahan Bahasa Indonesia. Pada akhir kuliah, mahasiswa diharapkan mampu menulis karya ilmiah (skripsi) atau laporan penelitian, dan membuat proposal penelitian dengan menerapkan kaidah ejaan dan menyikapi konsep-konsep struktur bahasa Indonesia yang terdapat dalam Tata Bahasa Baku Bahasa Indonesia. STA (1988: 
109, dalam Sukarto (2016 63 - 64) menyebutnya dengan istilah bahasa yang normatif yakni agar kita dapat membedakan aturan yang perlu dan menguntungkan bahasa Indonesia. Dengan kata lain, kita hendaknya dapat menyesuaikan diri kepada cara berpikir yang secara modern, dengan menyikapi kaidah-kaidah yang berlaku yang tidak bersangkut paut dengan syarat-syaratberpikir.

Paparan di atas, menunjukkan betapa pentingnya bahasa Indonesia untuk keperluan pengembangan ilmu pengetahuan dan teknologi, khususnya dalam era milenial ini. Begitu cepatnya pengembangan teknologi dalam era global. Oleh karena itu, dengan cara menyikapi bahasa Indonsia secara positif dan menyikapi kaidah bahasa Indonesia yang telah ditulis dalam pedoman-pedoman bahasa Indonesia, maka kedudukan dan funsgsi bahasa Indonesia dan sebagai bahasa negara semakin kokoh.

\section{Ejaan}

Ejaan adalah berhubungan dengan ragam bahasa tulis, dan sarana kebahasaannya adalah huruf dan tanda baca (Hakim; Arifin; Lumintaintang, 1992: 3). Dalam ejaan itu telah tercakup kaidah yakni tentang kaidah pemakaian huruf, penulisan kata pemakaian tanda baca, dan sejarah ejaan. Sehubungan dengan itu, kaidah yang ada dalam ejaan hendaknya diterapkan dalam penulisan tugas karya ilmiah mahasiswa. Sementara itu, Sukarto (2018:37) menyatakan, ejaan adalah kaidah cara menggambarkan bunyi bahasa dalam kata dan kalimat dalam bentuk tulisan yakni huruf dan tanda baca. Pernyaatan ini dilandasi adanya Pedoman Umum Ejaan Bahasa Indonesia. Edisi 2016. Pedoman ini termasuk pedoman terkini yang disusun oleh Tim Pengembang Pedoman Bahasa Indonesia, diterbitkan oleh Badan Pengembangan dan Pembinaan Bahasa, Kementerian Pendidikan dan Kebudayaan. Pedoman Ejaan terkini ini, mencakup pemakaian huruf, penulisan kata, pemakaian tanda baca, dan penulisan unsur serapan.

Berdasarkan ikhwal ejaan di atas, mahasiswa dalam menulis tugas karya ilmiah, hendaknya menyikapi kaidah-kaidah ejaan. Dengan cara itu, hasil tulisannya akan lebih baik jika dibandingkan dengan mahasiswa yang belum membaca atau memahami ikhwal ejaan bahasa Indonesia. Yang terjadi adalah ketika mahasiswa menulis ada saja yang cenderung tidak memperhatikan ejaan dalam tulisannya. Penerapan ejaan adalah penting karena berkaitan dengan makna, jika penempatan tanda baca keliru juga mengakibatkan adanya keambiguan makna pada kalimat yang ditulisnya.

\section{Diksi}

Diksi atau pemilihan kata yang tepat adalah cara yang tepat untuk memilih kata diterpakan dalam tulisan, baik tulisan ilmiah maupun nonilmiah. Untuk itu, menurut Achmad H.P. dan Alek (2016: 144) menyatakan bahwa penggunaan diksi (pemilihan kata) dalam penulisan ilmiah atau karya fiksi menjadi aspek yang sangat penting dalam membangun kalimat efektif dan utuh. Oleh karena itu, dalam tulisan karya ilmiah khususnya bagi mahasiswa yang sedang menulis tugas karya ilmiah merupakan hal yang penting untuk dimengerti dan dipahami ikhwal diksi ini. Mahasiswa yang sedang menulis tugas karya ilmiah jika belum menyikapi 
sepenuhnya pentingnya diksi ini, maka hasil tulisannya akan terlihat pilihan kata yang kurang tepat, sehingga akan menimbulkan makna kata yang ambigu.

Dalam kaitan dengan diksi itu, sikap positif atau kinerja kita dalam memilih kata yang tepat sesuai dengan konteksnya perlu dikembangkan. Dengan sikap bahasa yang positisf yang diawali dengan memilih kata yang tepat dalam setiap tulisan baik tulisan fiksi maupun ilmiah, tulisan seseorang akan semakin berkualitas. Dengan demikian, apa yang diancangkan dalam tuisannya, makna tulisan baik fiksi maupun nonfiksi dapat diterima atau dipahami oleh pembaca atau pendengar.

\section{Pengalimatan}

Pengalimatan adalah proses membuat kalimat yang efektif dalam sebuah karangan baik karangan ilmihan maupun nonilmiah. Pengalimatan ini lazim disebut kalimat efektif. Kalimat efektif adalah kalimat yang dapat dipahami secara jelas, lugas, dan informatif (Sukarto, 2018: 143). Jelas, bahwa dalam kalimat efektif harus jelas struktur kalimatnya. Lugas, berarti dalam kalimat efektif tidak menunjukkan adanya tafsir ganda. Informatif, berarti dalam kalimat yang ditulis, makna tulisannya jelas dan informasinya dapat berterima oleh pembaca.

Sehubungan dengan paparan di atas, Widiastuti (1995: 11) telah menghimpun pakar bahasa Indonesia yang berjudul Panduan Pustaka: Kalimat Efektif Bahasa Indonesia yang diterbitkan oleh Pusat Pembinaan dan Pengembangan Bahasa, Departemen Pendidikan dan Kebudayan. Simpulannya, bahwa kalimat efektif adalah suatu kalimat disebut efektif jika dapat dikenali cirinya, yaitu keutuhan, pemusatan perhatian, dan keringkasan. Dengan kata lain, bahwa keutuhan suatu kalimat sangat dibutuhkan adanya kepaduan. Subjek dalam kalimat harus jelas karena jika kalimat tidak adanya subjek bisa dikatakan frasa bukan sebuah kalimat. Juga adanya hubungan antarfrasa harus jelas. Hubungan antargbagian harus jelas dan logis. Adanya bagianbagian kalimat yang dipentingkan, sehingga akan tampak adanya topik yang dipentingkan di awal atau di akhir paragraf. Adanya pemborosan kata, artinya keekonomian kata juga harus diperhatikan, kesesuaian konteks dalam sebuah kalimat juga perlu disikapi secara positif. Dasardasar pemikiran ini, sebagai dasar untuk menganalisis pengalimatan dalam karya tulis ilmiah mahasiswa.

\section{METODE PENELITIAN}

Metode penelitian ini adalah menggunakan metode eskriptif kualitatif, menurut Sugiyono (2010, dalam Imelda, 2014: 180) menyatakan bahwa penelitian kualitatif yang menjadi instrumen atau alat penelitian adalah peneliti itu sendiri. Peneliti mendeskripsikan data yang terdapat dalam sumber data yang terpilih berkualitas sesuai dengan ancangan penulisan. Selain itu, secara kualitatif berfungsi menetapkan fokus penelitian-sumber data, melakukan pengumpulan data, menilai kualitas data, menafsirkan data, membuat kesimplan dan temuannya.

Dalam penulisan ini, peneliti mengambil sumber tugas karya tulis ilmiah mahasiswa Universitas Pembangunan Nasional "Veteran" Jakarta, Semester empat, sejumlah 19 makalah. Makalah tersebut ditulis secara kelompok, masing-masing kelompok terdiri atas empat orang. Adapun data yang diamnbil dalam penelitian ini adalah secara sampel yaitu kasus kesalahan 
Jurnal Pujangga Volume 6, Nomor 1, Juni 2020

ISSN P 2443-1478

ISSN E 2443-148

ejaan, diksi, dan pengalimatan. Sampel penelitian ini adalah mahasiswa semester 4 pada tahun ajaran 2019/2020, Fakultas Ekonomi dan Bisnis, Jurusan Manajemen Akuntansi, sejumlah 76 orang. Rata-rata anggota kelompok adalah 4 orang mahasiswa.

\section{ANALISIS DAN PEMBAHASAN}

Di dalam menganalisis data ini, penulis memberi urutan kode kode data yaitu Kelompok $=\mathrm{K}, 4=$ kelompok empat, jumlah anggota kelompok, iii= halaman sumber data, $2020=$ tahun pembuatan tugas karya tulis ilmiah. Misalnya kelompok 4, terdiri ats 4 orang, halaman 3 romawi dan tahun ditulis (K/4/4/iii/2020). Langkah berikutnya adalah mendeskripsikan data yakni mencatat mahasiswa dalam menerapkan kaidah ejaan bahasa Indonesia, diksi dan pengalimatan. Tidak semua data diambil untuk dianalisis, melainkan diambil contoh sebagai sampel data.

\section{Penulisan Singkatan}

Penulisan singkatan dapat ditemukan kasus seperti berikut.

(1) Puji Syukur kami ucapkan ke hadirat Allah swt, yang masih memberikan kesempatan dan kesehatan sehingga Karya Tulis Ilmiah ini dapat diselesaikan dalam waktu yang telah ditetapkan. (K/4/4/iii/2020)

(2) Puji syukur kehadirat Allah Swt yang telah memberikan rahmat dan hidayah-Nya kami dapat menyelesaikan tugas makalah yang berjudul Pengaruh Peran Orang Tua Terhadap Pendidikan Anak Usia Dini ini dengan tepat pada waktunya.(K/1/5/iii/2020/)

(3) Assalamualaikum warahmatullahi Wabarakatuh syukur alhamdulillah kami panjatkan ke hadirat Allah SWT atas limpahan rahmat serta hidayah-Nya sehingga karya tulis ini dapat terselesaikan.(K/6/4/iii/2020)

(4) Puji dan syukur kami panjatkan kepada Allah swt., karena berkat rahmat-Nya kami dapat menyelesaikan karya tulis yang berjudul "Pengaruh Pendidikan Karakter Terhadap Perkembangan Pengetahuan Anak Usia Dini” tepat pada waktunya. (K/16/4/iii/2020)

Kesalahan penerapan ejaan (1) adalah Penyingkatan swt,yang seharusnya $S$ kapital, $w$ dan $t$ huruf kecil diakhiri tanda petik. Penempatan tanda koma (,) sebelum kata sehingga. Kalimat(2) kesalahan pada Swt yang tanpa diakiri tanda titik(.) Setelah hidayah-Nya seharusnya diberi tanda koma (,). Kalimat (3) SWT seharusnya ditulis Swt. Kalimat (4) swt., seharusnya ditulis Swt. sebelum kata karena juga tidak harus diberi tanda koma (,). Jadi, kesalahan ejaan pada kalimat (1)—(4), seharusnya dapat diperbaiki seperti berikut ini.

(1a) Puji Syukur kami ucapkan ke hadirat Allah Swt. yang masih memberikan kesempatan dan kesehatan sehingga Karya Tulis Ilmiah ini dapat diselesaikan dalam waktu yang telah ditetapkan.(K4/4/iii/2020)

(2a) Puji syukur kehadirat Allah Swt. yang telah memberikan rahmat dan hidayah-Nya, kami dapat menyelesaikan tugas makalah yang berjudul Pengaruh Peran Orang Tua Terhadap Pendidikan Anak Usia Dini ini dengan tepat pada waktunya.(K/1/5/iii/2020/) 
(3a) Assalamualaikum warahmatullahi Wabarakatuh syukur alhamdulillah kami panjatkan ke hadirat Allah Swt., atas limpahan rahmat serta hidayah-Nya, sehingga karya tulis ini dapat terselesaikan.(K/6/4/iii/2020)

(4a) Puji dan syukur kami panjatkan kepada Allah Swt. karena berkat rahmat-Nya, kami dapat menyelesaikan karya tulis yang berjudul "Pengaruh Pendidikan Karakter terhadap Perkembangan Pengetahuan Anak Usia Dini” tepat pada waktunya. (K/16/4/iii/2020)

Begitu pula pada singkatan pada kaliamt (5) seprti berikut.

(5) Shalawat dan salam kami kirimkan kepada Nabi Muhammad SAW beserta Sahabat yang telah memberikan tauladan agar selamat di dunia dan akhirat. (K/6/4/iii/2020)

Seharusnya kalimt (5) seperti berikut ini.

(5a) Shalawat dan salam kami kirimkan kepada Nabi Muhammad saw. beserta sahabat yang telah memberikan teladan agar selamat di dunia dan akhirat. (K/6/4/iii/2020)

Kasus kesalahan penerapan ejaan adalah penulisan nama atau sifat Tuhan seperri berikut ini.

(6) Puji dan syukur kita panjatkan kehadapan Tuhan Yang Maha Kuasa, karena berkat dan rahmat-Nya peneliti mendapat kekuatan, semanagat, pikiran yang kuat sehingga dapat menyelesaikan penulisan karya ilmiah ini. (K/3/4/iii/ 2020)

Kasus kesalahan ejaan pada kalimat (6) adalah penulisan kata Kuasa seharusnya dirangkaiakan dengan kata Maha. Hal itu sesuai dengan kaidah ejaan yang menyatakan bahwa "Bentuk maha yang diikuti kata dasar yang mengacu pada nama atau sifat Tuhan, kecuali kata esa, ditulis serangkai”. Selain itu, sebelum kata karena tidak harus diberintanda koma (,). Setelah kata rahmat-Nya seharysnya diberi tanda koma (,)

Jadi kalimat (6) seharusnya seperti berikut.

(6a) Puji dan syukur kita panjatkan kehadapan Tuhan Yang Mahakuasa karena berkat dan rahmat-Nya, peneliti mendapat kekuatan, semangat, pikiran yang kuat sehingga dapat menyelesaikan penulisan karya ilmiah ini. (K/3/4/iii/ 2020)

\section{Penulisan Singkatan Gelar}

Penulisan singkatan gelar akademik biasanya masih diabaikan, belum disikapi secara positif oleh mahasiswa. Meskipun begitu, mahasiswa ada juga yang sudah menyikapi kaidahnya dengan baik. Untuk itu, kasus yang muncul adalah sepeti berikut.

(7) Kami mengucapkan terima kasih kepada DR. Kasno Artmo Sukarto, M.Pd. dan Dr. Nini Ibrahim selaku Dosen Pengampu Mata Kuiah Bahasa Indonesia yang telah memberikan pengetahuan dan wawasan sesuai dengan mata kuliah yang kami tekuni. ( K/2/4/iii/ 2020) 
Jurnal Pujangga Volume 6, Nomor 1, Juni 2020

ISSN P 2443-1478

ISSN E 2443-148

(8) Oleh karena itu, kami ingin berterima kasih kepada dosen Bahasa Indonesia Bapak DR. Kasno Atmo Sukarto dan Ibu Prima Dwi Yuliani, M,Pd serta teman-teman yang telah membantu menyelesaikan karya tuis kami ....(K/11/4/2/2020)

Kalimat (7) dan (8) pada penulisan singkatan gelar, jika nama ditulis hanya huruf awal kapital, Berarti singkatan gelar yang haruf awal $D$ yang kapital, kedua huruf $R$ ditulis dengan huruf kecil. Jika di depan sudah disebut Ibu atau Bapak cukup menambahkan gelar di belakang nama yang bersangkutan. Akan tetapi, jika di depan nama sudah disebutkan gelarnya, penulis tudak harus menulis Bapak atau Ibu di depan gelarnya. Berkaitan dengan gelar tersebut, penulisan singkatan gelar di belakang nama, juga harus diikuti tandaa titik. Misalnya Ibu Prima Dwi Yuliani, M,Pd seharusnya ditulis Ibu Prima Dwi Yuliani, M.Pd. Dengan demikian, kesalahan penulisan ejaan (tanda baca titik) pada kalimat (7) dan (8) seharusnya sebagai berikut.

(7a) Kami mengucapkan terima kasih kepada Dr. Kasno Artmo Sukarto, M.Pd. dan Dr. Nini Ibrahim selaku dosen Pengampu Mata Kuliah Bahasa Indonesia yang telah memberikan pengetahuan dan wawasan sesuai dengan mata kuliah yang kami tekuni. ( K/2/4/iii/ 2020)

(8a) Oleh karena itu, kami ingin berterima kasih kepada dosen Bahasa Indonesia Dr. Kasno Atmo Sukarto dan Ibu Prima Dwi Yuliani, M.Pd., serta teman-teman yang telah membantu menyelesaikan karya tuis kami ....(K/11/4/2/2020)

\section{Penulisan Nama dalam sebuah Kutipan}

Mahasiswa dalam menulis tugas karya ilmiah, ketika sulit untuk mengembangkan kalimat yang dibuatnya, tidak ada jalan lain kecuali harus mengutif. Dalam mengutif, mahasiswa cenderung menulis secara keseluruahan nama lengkapnya. Hal itu dilakukan karena belum memahami secara utuh bagaimana cara mengutif yang benar. Untuk itu, kita lihat pada kasus berikut ini.

(9) Sugihartono, dkk (2003:3) menyatakan"pendidikan adalah suatu usaha yang dilakukan secara sadar dan sengaja untuk mengubah tingkah laku manusia baik secara individu maupun kelompok untuk mendewasakan manusia melalui upaya pengajaran dan pelatihan". (K/16/4/5/2020)

(10) Menurut Yahya Khan, D (2010: 1) "Pendidikan berarti proses pengembangan berbagai macam potensi yang ada dalam diri manusia agar dapat berkembang dengan baik dan bermanfaat bagi dirinya dan juga lingkungannya. (K/16/4/5/2020)

(11) Menurut (Dwi Siswoyo, 2008: 19) "Pendidikan adalah proses dimana masyarakat, melalui lembaga pendidikan dengan sengaja mentranformasikan warisan budayanya, yaitu pengetahuan, nilai-nilai dan ketrampilan dari generasi ke generasi. (K/16/4/5/2020)

Kesalahan pada kalimat (9) adalah dkk singkatannya tanpa diakhiri tanda titik (.), penulisan setelah tanda titik dua (:) spasi baru ditulis nomor halaman. Kalimat (1) penulisan nama untuk kutipan cukup nama belakang saja yang ditulis, tetapi setelah nama Khan ada D tanpa tanda titik (.) tulisannya bisa Khan D. Untuk Kalimat nomor (11) nama Dwi Siswoyowo, cukup ditulis Siswoyo saja di luar tanda kurung. Dengan catatan, apabila ingin 
menempatkan nama di dalam kurung, nama penulis harus ditulis di belakang kutipannya. Oleh karena itu, kalimat (9), (10), dan (11) seperti berikut.

(9a) Sugihartono, dkk. (2003: 3) menyatakan"pendidikan adalah suatu usaha yang dilakukan secara sadar dan sengaja untuk mengubah tingkah laku manusia baik secara individu maupun kelompok untuk mendewasakan manusia melalui upaya pengajaran dan pelatihan". (K/16/4/5/2020)

(10a) Menurut Khan D. (2010: 1) "Pendidikan berarti proses pengembangan berbagai macam potensi yang ada dalam diri manusia agar dapat berkembang dengan baik dan bermanfaat bagi dirinya dan juga lingkungannya. (K/16/4/5/2020)

(11a) Menurut Siswoyo (2008: 19) "Pendidikan adalah proses di mana masyarakat, melalui lembaga pendidikan dengan sengaja mentransformasikan warisan budayanya, yaitu pengetahuan, nilai-nilai dan keterampilan dari generasi ke generasi. (K/16/4/5/2020)

(11b) "Pendidikan adalah proses di mana masyarakat, melalui lembaga pendidikan dengan sengaja mentransformasikan warisan budayanya, yaitu pengetahuan, nilai-nilai dan keterampilan dari generasi ke generasi. (Siswoyo, 2008: 1). (K/16/4/5/2020)

\section{Penulisan Unsur Asing}

Penulisan unsur asing juga sering tidak disikapi oleh penulis tugas karya ilmiah. Hal ini, dapat dilihat pada kasus berikut.

(12) Pengaruh pembelajaran online terhadap prestasi belajar kimia ditinjau dari kemampuan awal siswa.(K/15/4/12/2020)

(13) Hasil penelitian ini menunjukkan bahwa pembelajaran online dapat digunakan untuk meningkatkan prestasi belajar.(K/15/4/12/2020)

Dalam kalimat (12) dan (13) terdapat kekeliruan daalam menulis unsur asing (bahasa Inggris). Oleh karena itu, yang tepat tulisannya hendaknya dimiringkan. Tujuannya agar ada perbedaan antara paparan dan yang dipaparkan. Jadi kalimat (2) dan (13) yang benar adalah seperti berikut.

(12a) Pengaruh pembelajaran online terhadap prestasi belajar kimia ditinjau dari kemampuan awal siswa.(K/15/4/12/2020)

(13a) Hasil penelitian ini menunjukkan bahwa pembelajaran online dapat digunakan untuk meningkatkan prestasi belajar.(K/15/4/12/2020)

\section{Diksi}

Diksi atau piliahan kata juga penting bagi mahasiswa dalam sebuah kalimat. Jika mahasiswa dalam menulis salah memilih kata, berarti makna apa yang ada di dalam kalimat akan menjadi ambigu atau salah makna yang tidak sesuai dengan tujuan penulisan. Hal itu, dapat kita lihat pada kasus berikut ini. 
(14) Shalawat dan salam kami kirimkan kepada Nabi Muhammad SAW beserta Sahabat yang telah memberikan tauladan agar selamat du dunia dan akhirat. (K/6/4/iii/2020)

(15) Hal ini disebabkan karena penggunaan teknologi informasi dan internet masih rendah sehngga wajib pajak masih banyak yang terlambat dalam menyampaikan SPT dan membayarkan pajak terutangnya. (K/6/4/57/2020)

Kalimat (14) pilihan kata shalawat yang baku selawat, SAW seharusnya saw., Sahabat yang benar sahabat, sedangkan tauladan seharusnya teladan. Kalimat (15) penggunaan kata disebabkan karena kurang tepat dalam memilih kata karena kedua kata itu bentuk beda makna sama. Jadi, untuk kalimat (15), kedua kata itu bisa dipakai, hanya harus memilih salah satu. Jadi, kalimat (14) dan (15) yang efektif seperti berikut.

(14a) Selawat dan salam kami kirimkan kepada Nabi Muhammad saw., beserta sahabat yang telah memberikan teladan dan agar selamat di dunia dan akhirat. (K/6/4/iii/2020)

(15a) Hal ini disebabkan penggunaan teknologi informasi dan internet masih rendah sehingga wajib pajak masih banyak yang terlambat dalam menyampaikan SPT dan membayarkan pajak terutangnya. (K/6/4/57/2020)

(15b) Hal ini dikarenakan penggunaan teknologi informasi dan internet masih rendah sehngga wajib pajak masih banyak yang terlambat dalam menyampaikan SPT dan membayarkan pajak terutangnya. (K/6/4/57/2020)

\section{Pengalimatan}

Pengalimatan yang dimaksud adalah kalimat efektif dalam sebuah tugas karya tulis ilmiah mahasiswa. Oleh karena itu, penulis ingin mendeskripsikan dan menganalisis kasus kalimat yang dibuat oleh mahasiswa.

\section{Ekonomi Bahasa}

Dalam tugas karya tulis mahasiswa terdapat adanya penulisan yang kurang efektif misalnya adanya ekonomi bahasa. Ekonomi bahasa adalah bahwa dalam sebuah kalimat hendaknya tidak boros dalam menggunakan kata atau dalam memilih kata. Semakin tepat dalam memlih kata berarti semakin efektif dalam membuat kalimat. Hal itu dapat kita lihat pada kasus berikut.

(16) Hal ini disebabkan karena penggunaan teknologi informasi dan internet masih rendah sehngga wajib pajak masih banyak yang terlambat dalam menyampaikan SPT dan membayarkan pajak terutangnya. (K/6/4/57/2020)

Kalimat (16) seharusnya dapat memilih salah satu kata yaitu disebabkan atau karena/dikarenakan. Dengan demikian kaliamat (16) seperti berikut ini.

(16a) Hal ini disebabkan penggunaan teknologi informasi dan internet masih rendah sehingga wajib pajak masih banyak yang terlambat dalam menyampaikan SPT dan membayarkan pajak terutangnya. (K/6/4/57/2020) 
(16b) Hal ini dikarenakan penggunaan teknologi informasi dan internet masih rendah sehngga wajib pajak masih banyak yang terlambat dalam menyampaikan SPT dan membayarkan pajak terutangnya. $(\mathrm{K} / 6 / 4 / 57 / 2020)$

\section{Penggunaan Konjungsi yang Kurang Tepat}

Di dalam sebuah kalimat, pemakaian konjungsi yang salah akan memengaruhi makna kalimat yang dibuat. Dengan demikain, kalimat yang dibuat tidak akan efektif. Untuk itu dapat dilihat pada kasus berikut.

(17) Tapi ada faktor lain yang mendorong untuk melakukan pembelian secara online dan konsumtif seperti faktor kemudahan, harga dan faktor lain yang tidak disebutkan dalam penelitian ini. $(\mathrm{K} / 2 / 4 / 12 / 2020)$

Penggnaan konjungsi tetapi dalam dalam kalimat (17) adalah kurang tepat. Konjngsi tetapi merupakan konjungsi setara dalam kalimat majemuk setara. Agar lebih tepat, penulis data menggunakan konjungsi anta rkalimat yaitu dengan menggunakan konjungsi akan tepai, ..., Namun, ... untuk mengawali sebuah kalimat. Dengan demikian kalimat (17) sepeti berikut.

(17a) Akan tetapi, ada faktor lain yang mendorong untuk melakukan pembelian secara online dan konsumtif seperti faktor kemudahan, harga dan faktor lain yang tidak disebutkan dalam penelitian ini. $(\mathrm{K} / 2 / 4 / 12 / 2020)$

(17b) Namun, ada faktor lain yang mendorong untuk melakukan pembelian secara online dan konsumtif seperti faktor kemudahan, harga dan faktor lain yang tidak disebutkan dalam penelitian ini. $(\mathrm{K} / 2 / 4 / 12 / 2020)$

Kasus sejenis dapat kita lihat pada kalimat berikut.

(18) Sehingga saat ini mahasiswa dapat memperoleh ilmu tidak hanya melalui buku namun bisa melalui internet. $(\mathrm{K} / 15 / 4 / 1 / 2020)$

Kalimat (18) penggunaan konjungsi sehingga kurang tepat. Konjungi sehingga sebagai konjungsi subordinatif. Konjungsi namun merupakan konjungsi antarparagraf. Oleh karena itu, kalimat (18) seharusnya seperti berikut.

(18a) Saat ini mahasiswa dapat memperoleh ilmu tidak hanya melalui buku, tetapi bisa melalui internet. $(\mathrm{K} / 15 / 4 / 1 / 2020)$

\section{Ketidakjelasan Subjek}

Jika dalam sebuah kalimat tidak ada subjek berarti itu bukan kalimat melainkan frasa. Sementara klausa pun sudah ada unsur subkjeknya. Jadi, hal itu dapat dilihat pada kalimat berikut.

(19) Dari pengertian para ahli di atas, terkait dengan peranan orang tua dalam pendidikan anak usia dini. (K/1//9/2020) 
Jurnal Pujangga Volume 6, Nomor 1, Juni 2020

ISSN P 2443-1478

ISSN E 2443-148

(20) Untuk melaksanakan metode observasi sebaik-baiknya perlu latihan dan pengalaman yang cukup. (K/1//19/2020)

(21) Dalam rangka memenuhi tugas akhir mata kuliah Bahasa Indonesia. Kami bermaksud mengadakan penelitian untuk mengetahui pengaruh dari penggunaan pembayaran nontunai. (k/18/4/22/2020)

(22) Memberikan pendidikan sejak usia dini kepada anak-anak berusia balita. (K/16/4/1/2020)

Kalimat (19) belum terlihat adanya subjek. agar jelas subjeknya, kata terkait dengan dapat dihilangkan. Kalimat (20) juga belum adanya subjek. Untuk itu, setelah kata sebaikbaiknya perlu dijeda dengan tanda koma (,) setelah koma diberi subjek sesuai dengan konteksnya. Kalimat (21) setelah kata bahasa Indonesia tidak perlu diberi tanda titi(.) karena subjeknya juga belum jelas. Agar jelas subjeknya cukup dengan mengganti tanda titik (.) Kalimat dengan tanda koma (,). Kalimat (22) Subjeknya juga belum jelas, agar jelas subjeknya sebelum kata memberikan harus ada subjek dengan demikian, kalimat (19), (20), (21), dan (22) seperti berikut.

(19a) Dari pengertian para ahli di atas, orang tua berperan dalam pendidikan anak usia dini. $(\mathrm{K} / 1 / / 9 / 2020)$

(20a) Untuk melaksanakan metode observasi sebaik-baiknya, mahasiswa perlu latihan dan pengalaman yang cukup. (K/1//19/2020)

(21) Dalam rangka memenuhi tugas akhir mata kuliah Bahasa Indonesia, kami bermaksud mengadakan penelitian untuk mengetahui pengaruh penggunaan pembayaran nontunai. $(\mathrm{k} / 18 / 4 / 22 / 2020)$

(22) Guru dapat memberikan pendidikan sejak usia dini kepada anak-anak berusia balita.

$(\mathrm{K} / 16 / 4 / 1 / 2020)$

\section{PENUTUP}

Simpulan

Secara sampel laporaran tugas karya ilmiah mahasiswa Universitas Pembangunan Nasional"Veteran", Fakultas Ekonomi dan Bisnis, Jurusan Manajemen Akuntansi, Jakarta dapat disimpulkan bahwa dalam tulisannya itu masih terdapat adanya kesalahan seperti berikut ini. Pertama, masih terdapat adanya kesalahan penerapan ejaan khusunya penulisan singkatan nama sifat Tuhan, singkatan gelar, penulisan nama dalam sebuah kutipan, dan penulisan unsur-unsur bahasa asing. Kedua, pilihan kata yang kurang tepat, belum sesuai dengan konteksnya. Ketiga, dalam pengalimatan masih terdapat kekeliruan dalam membuat kalimat, seperti kurang cermat dalam menyikapi atau menerapkan ekonomi bahasa, konjungsi, dan ketikdakjelasan subjek.

\section{Saran}

Di dalam analisis ini, masih banyak masalah ejaan, diksi, dan pengalimatan yang belum seluruhnya dianalisis. Oleh karena itu, disarankan kepada peneliti bidang sejenis untuk meneliti, misalnya masalah ejaan, yang berkaitan dengan pemakian huruf kapital dan huruf miring. 
Penulisan kata, misalnya kata berimbuhan, pemenggalan kata, termasuk bentuk kata. Pemakaian tanda baca, misalnya penggunaan titik dua, tanda petik dua, atau petik satu. Penulisan unsur serapan perlu dilakukan karena untuk membedakan kata dan istilah sebagai bahasa papapran atau kutipan. Selain itu, masalah pengalimatan yang perlu diteliti misalnya masalah kesepadanan, kepararelan, ketegasan, kehematan, dan kevariasian. 


\section{DAFTAR PUSTAKA}

Achmad H.P. dan Alek. 2016. Bahasa Indonesia untuk Perguruan Tinggi: Substanssi Kajian dan Penerapannya. Jakarta: Erlangga.

Hakim, Lukman: Zaenal Arifin; Yayah B. Lumintaintang. 1992. Ejaan dalam Bahasa Indonesia: Seri Penyuluhan 1. Jakarta: Pusat Pembinaan dan Pengembangan Bahasa, Departemen Pendidikan dan Kebudayaan.

Imelda. 2014. "Analisis Penggunaan Huruf Kana oleh Mahasiswa Bahasa Jepang Program Stutudi Sastra Jepang Universitas Hasanuddin. Dalam Widyaparwa. Volume 42. Nomor 2. Desember.

Kasno. 2012. "Ragam Bahasa Majalah Remaja: Suatu Analisis Isi”. Disertasi. Universitas Negeri Jakarta.

Martin; Mustakim; Martha Lena Adriana. 1995. Pemakaian Bahasa Indonesia Ragam Tulis di Lingkungan Perguruan Tinggi. Jakarta: Pusat Pembinaan dan Pengembangan Bahasa, Departemen Pendidikan dan Kebudayaan.

Sugiyono dan Wisnu Sasongko. 2014. "Sikap Bahasa Masyarakat Perkotaan Kalimantan". Dalam Widyaparwa. Volume 42. Nomor 2. Desember.

Sugono, Dendy. 1997. Berbahasa Indonsia dengan Benar. Jakarta. Puspa Swara.

Sukarto, Kasno Atmo. 2018. "Bahasa Indonesia yang Baik dan Benar: Suatu Ancangan Pembinaan dan Pengembangan Bahasa. Dalam Pujangga. Volume 4. Nomor 2. Desember.

Sukarto, Kasno Atmo. 2018. Bahasa Indonesia: Dasar-Dasar Pengembangan Kepribadian. Kota Tangerang: Pustaka Mandiri.

Tim Pengembang Pedoman Bahasa Indonesia. 2016. Pedoman Umum Ejaan Bahasa Indnesia. Jakarta: Badan Pengembangan dan Pembinaan Bahasa, Kementerian Pendidikan dan Kebudayaan. 